\title{
ASUPAN LEMAK DAN KADAR HIGH DENSITY LIPOPROTEIN (HDL) SEBAGAI FAKTOR RISIKO PENINGKATAN KADAR C-REACTIVE PROTEIN (CRP) PADA REMAJA OBESITAS DENGAN SINDROM METABOLIK
}

\author{
Sani Rachmawati, Muhammad Sulchan*) \\ Program Studi Ilmu Gizi Fakultas Kedokteran Universitas Diponegoro \\ Jl.Dr.Sutomo No.18, Semarang, Telp (024) 8453708, Email : gizifk@ undip.ac.id
}

\begin{abstract}
Background: Increasing obesity prevalence among adolescents was followed by increasing incidence of metabolic syndrome, which is influenced by the selection of high-fat foods. Adolescents with metabolic disorder have a risk for increasing C-reactive protein (CRP) levels, which is an indicator of metabolic disorders and cardiovascular disease risk in adulthood. This study aims to determine the risk of fat intake and HDL levels against increased CRP levels in obese adolescents with metabolic syndrome.

Methods: A cross sectional study was conducted in students of SMAN 2 Semarang. Subject were selected based on the inclusion criteria with minimal sample was 38. Determination of metabolic syndrome is defined as the presence of at least 3 of the following risk factor: waist circumference $\geq 90^{\text {th }}$ percentile, blood pressure $\geq 90^{\text {th }}$ percentile, triglycerides $\geq 110 \mathrm{mg} / \mathrm{dl}$, HDL levels $\leq 40 \mathrm{mg} / \mathrm{dl}$, and fasting blood glucose levels $\geq 110 \mathrm{mg} / \mathrm{dl}$. Data of saturated fatty acids and cholesterol intake were obtained using food frequency questionnaire (FFQ) method. Data analysis were performed using Pearson and Spearman tests to examine the correlation between fat intake and HDL levels with CRP levels, while to examine risk value were calculated with Prevalent Ratio (PR).

Results: Of the 835 adolescents, 80 (9,58\%) were overweight, 66 (7,9\%) were obese, and 61 (7,3\%) were central obesity. The prevalence of metabolic syndrome in obese adolescents was 15.2\%. There was a significant correlation between intake of saturated fatty acids and dietary cholesterol with CRP levels.

Conclusions: High intake of saturated fatty acids, higher intake of cholesterol, and low HDL levels are risk factor for increasing levels of CRP in obese adolescents with metabolic syndrome, with the risk value 3.6 times; 7,6 times; and 1.2 times higher respectively.

Keyword :Metabolic syndrome, obesity, adolescent, High Density Lipoprotein, C-Reactive Protein.
\end{abstract}

\begin{abstract}
ABSTRAK
Latar belakang: Peningkatan prevalensi obesitas pada remaja yang diikuti dengan peningkatan kejadian sindrom metabolik, salah satunya dipengaruhi oleh pemilihan makanan tinggi lemak. Remaja dengan kelainan metabolik berisiko mengalami peningkatan kadar C-Reactive Protein yang merupakan indikator terhadap gangguan metabolik dan berisiko mengalami penyakit kardiovaskuler saat dewasa. Penelitian ini bertujuan untuk mengetahui besar risiko asupan lemak dan kadar HDL terhadap peningkatan kadar CRP pada remaja obesitas dengan sindrom metabolik.
\end{abstract}

Metode : Desain penelitian ini adalah belah lintang yang dilakukan pada populasi siswa SMA Negeri 2 Semarang. Subyek dipilih berdasarkan kriteria inklusi dengan jumlah sampel minimal 38 orang. Penentuan sindrom metabolik apabila terdapat sedikitnya 3 dari faktor risiko berikut: lingkar pinggang $\geq$ persentil ke -90, tekanan darah $\geq$ persentil ke -90 , trigliserida $\geq 110 \mathrm{mg} / \mathrm{dl}$, HDL $\leq 40 \mathrm{mg} / \mathrm{dl}$, dan glukosa darah puasa $\geq 110 \mathrm{mg} /$ dl. Data asupan asam lemak jenuh dan asupan kolesterol diperoleh melalui Food Frequency Questionnaire (FFQ). Analisis data dilakukan dengan menggunakan uji Pearson dan Spearman untuk mengetahui hubungan antara asupan lemak dan kadar HDL dengan kadar CRP, sementara untuk menguji besar risiko dihitung dengan nilai rasio prevalensi (RP) Hasil : Dari 835 remaja, 80 (9,58\%) overweight, 66 (7,9\%) obesitas, dan 61 (7,3\%) obesitas sentral. Prevalensi sindrom metabolik pada remaja obesitas adalah 15,2\%. Ditemukan hubungan yang signifikan antara asupan asam lemak jenuh dan asupan kolesterol dengan kadar CRP.

Simpulan : Asupan tinggi asam lemak jenuh, asupan tinggi kolesterol, dan kadar HDL yang rendah merupakan faktor risiko terhadap peningkatan kadar CRP pada remaja obesitas dengan sindrom metabolik, dengan besar risiko 3,6 kali; 7,6 kali; dan 1,2 kali.

Kata Kunci : Sindrom metabolik, obesitas, remaja, High Density Lipoprotein, C-Reactive Protein

\section{PENDAHULUAN}

Sindrom metabolik sangat erat hubungannya dengan peningkatan risiko terhadap penyakit jantung koroner dan diabetes mellitus tipe $2 .{ }^{1}$
Sindrom metabolik tidak hanya dialami pada usia dewasa saja, akan tetapi sudah muncul pada usia anak-anak dan remaja. Peningkatan angka kejadian sindrom metabolik sejalan dengan meningkatnya

${ }^{*}$ Penulis Penanggungjawab 
kasus obesitas sentral. Berdasarkan data dari National Cholesterol Education Program / Adult Treatment Panel III (NCEP-ATP III) menunjukkan remaja dengan Indeks Masa Tubuh (IMT) pada persentil > 95 mengalami sindrom metabolik sebesar $32,1 \%{ }^{2}$ Sementara prevalensi sindrom metabolik di Indonesia diperoleh melalui penelitian yang dilakukan pada siswa SMP di Semarang diketahui prevalensi sindrom metabolik pada remaja yang obes adalah $31,6 \%$. 3,4

Obesitas yang terjadi pada masa remaja berisiko tinggi menjadi obesitas di masa dewasa dan dapat meningkatkan morbiditas dan mortalitas. Penimbunan lemak berlebih yang terjadi sejak dini merupakan faktor risiko terjadinya penyakit degeneratif pada masa dewasa. Obesitas yang terjadi pada remaja dipengaruhi oleh faktor genetik dan lingkungan, dimana faktor lingkungan yang berpengaruh kuat terhadap kejadian obesitas adalah asupan makan pada remaja.

Asupan zat gizi pada remaja sangat menentukan kematangan mereka di masa depan, sehingga pemilihan jenis makanan yang tepat bagi remaja merupakan hal yang penting untuk mencapai pertumbuhan yang optimal. Jenis makanan yang dipilih oleh remaja pada masa kini lebih condong pada pangaruh western. Hal ini berpengaruh pada pemilihan makanan ke arah unhealthy food yang merupakan makanan tinggi lemak, tinggi energi, dan rendah serat, dimana jenis makanan tersebut banyak ditemui pada makanan siap saji (fast food). Berdasarkan penelitian yang dilakukan di Amerika menunjukkan lebih dari $90 \%$ remaja selalu makan camilan yang sebagian besar kandungannya adalah lemak diantara waktu makan. ${ }^{5}$

Lemak memberi tekstur yang disukai dan pemberi kelezatan khusus pada makanan. Hal inilah yang mendorong sebagian besar remaja suka mengkonsumsi makanan yang mengandung lemak dalam jumlah yang tinggi karena rasanya yang enak. Makanan tinggi lemak yang dikonsumsi dalam jumlah banyak dapat menyebabkan kelebihan energi bila tidak diimbangi dengan pengeluaran energi yang sesuai, sehingga menyebabkan peningkatan penyimpanan energi dalam sel lemak yang mengakibatkan terjadinya obesitas. Keadaan obesitas yang muncul berhubungan dengan berbagai gangguan termasuk gangguan pada insulin dan gangguan reaksi adipokin sehingga memicu munculnya inflamasi tingkat rendah. Salah satu faktor yang dapat mengaktifkan reaksi inflamasi tersebut adalah asupan lemak terutama asam lemak jenuh (saturated fatty acid), dan kolesterol. Jumlah dan proporsi asupan lemak jenuh dan asupan kolesterol memberikan kontribusi terhadap perkembangan inflamasi tingkat rendah yang berhubungan dengan gangguan metabolik. ${ }^{6}$ Berdasarkan penelitian yang dilakukan pada tahun 2005 menunjukkan peningkatan konsumsi asam lemak jenuh berhubungan dengan status proinflamasi. ${ }^{7}$

Asupan lemak tidak hanya berpengaruh pada reaksi inflamasi tetapi juga berpengaruh pada profil lipid darah yakni berperan dalam peningkatan kadar kolesterol LDL dan menurunkan kadar kolesterol HDL yang menjadi penyebab terjadinya dislipidemia. ${ }^{8}$ Kadar HDL yang rendah akan berpengaruh pada rasio total kolesterol yang dapat digunakan untuk memprediksi risiko penyakit jantung koroner. Berdasarkan hasil penelitian menunjukkan penurunan HDL sebanyak $1 \mathrm{mg} / \mathrm{dl}$ dapat meningkatkan risiko terhadap penyakit jantung koroner sebesar 2-3\%. ${ }^{9}$

Rendahnya kadar HDL merupakan salah satu kriteria dari sindrom metabolik. Berdasarkan National Health and Nutrition Examination Survey (NHNES) tahun 2001-2006 menyebutkan prevalensi sindrom metabolik pada remaja berusia 12-19 tahun adalah $8,6 \%$ dengan $19,3 \%$ diantaranya memiliki kadar kolesterol HDL yang rendah. ${ }^{1}$ Berdasarkan penelitian epidemiologi yang dilakukan pada anak berusia 4-18 tahun menunjukkan $17,4 \%$ anak mengalami sindrom metabolik dengan $80,6 \%$ diantaranya memiliki kadar kolesterol HDL yang rendah. ${ }^{10}$ Data yang ada di Indonesia menunjukkan bahwa prevalensi individu sindrom metabolik dengan konsentrasi kolesterol HDL yang rendah bekisar antara 40$73 \% .^{5}$

Sindrom metabolik berhubungan dengan indikator-indikator inflamasi seperti C-Reactive Protein (CRP). Inflamasi yang muncul berhubungan dengan peningkatan risiko terhadap penyakit jantung koroner dan dibetes, dimana risiko ini akan meningkat pada individu yang memiliki sindrom metabolik. ${ }^{2,11} \mathrm{CRP}$ merupakan penanda inflamasi sebagai respon terhadap berbagai rangsangan inflamasi baik inflamasi akut (infeksi) maupun inflamasi kronis. Kelebihan dari CRP adalah bersifat stabil, ketersediaan assay untuk pemeriksaan laboratorium mudah, ada standarisasi dari WHO, dan dapat mendeteksi inflamasi sampai tingkatan terendah (low grade inflammation). ${ }^{11,12}$

Remaja dengan kelainan metabolik berisiko mengalami peningkatan kadar CRP yang 
merupakan indikator terhadap gangguan metabolik dan berisiko mengalami penyakit kardiovaskuler saat dewasa. ${ }^{13}$ CRP merupakan salah satu penanda yang lebih mendalam pada kejadian sindrom metabolik yang merupakan prediktor untuk mengetahui risiko penyakit kardiovaskuler, dimana penyakit kardiovaskuler berhubungan dengan kadar HDL yang rendah. Berdasarkan penelitian yang dilakukan dalam sebuah populasi didapatkan peningkatan kadar CRP diikuti dengan menurunnya kadar kolesterol HDL. Penelitian di Semarang juga menunjukkan peningkatan kadar CRP berhubungan dengan peningkatan IMT dan persen lemak tubuh, tetapi tidak berhubungan dengan peningkatan profil lipid, kecuali HDL yang berbanding terbalik dengan CRP. ${ }^{4}$

Peningkatan kadar CRP pada remaja dengan sindrom metabolik merupakan prediktor terhadap perkembangan penyakit kardiovaskuler pada masa dewasa, akan tetapi penelitian tentang hubungan antara asupan makanan, biomarker inflamasi dan komponen sindrom metabolik pada remaja masih terbatas.

\section{METODE PENELITIAN}

Penelitian ini termasuk dalam ruang lingkup keilmuan gizi masyarakat dengan menggunakan desain peneltian cross-sectional. Populasi dalam penelitian ini adalah semua siswa usia 15-18 tahun di SMA Negeri 2 Semarang. Besar sampel yang digunakan dalam penentuan prevalensi sindrom metabolik sebanyak 47 orang yaitu subyek dengan obesitas sentral yang bersedia ikut serta dalam penelitian, sementara sampel yang diambil data asupan dan CRP sebesar 38 orang. Kriteria inklusi adalah berusia 15-18 tahun, mengalami obesitas yang ditandai dengan Indeks Massa Tubuh (IMT) terhadap umur dan jenis kelamin $\geq$ persentil ke-95, termasuk dalam kriteria pra sindrom metabolik yaitu mengalami obesitas sentral, tidak sedang mengkonsumsi obat-obatan, dan tidak dalam keadaan sakit. Kriteria eksklusi adalah subjek mengundurkan diri dalam penelitian dan subjek sakit atau meninggal saat penelitian berlangsung.

Variabel terikat pada penelitian ini adalah kadar (CRP), sedangkan variabel bebas adalah asupan asam lemak jenuh, asupan kolesterol, dan kadar kolesterol HDL. Pemilihan subyek penelitian, pengambilan sampel darah, dan wawancara asupan makan dilakukan pada bulan Mei 2014. Setiap subyek terpilih diberikan informed consent sebagai tanda subyek setuju ikut serta dalam penelitian, sementara pembuatan ethical clearance diajukan kepada Komite Etik
Penelitian Fakultas Kedokteran Universitas Diponegoro/RSUP Dr Kariadi Semarang.

Pemeriksaan yang dilakukan meliputi pengukuran antropometri, tekanan darah, dan pengambilan sampel darah untuk pemeriksaan parameter sindrom matabolik. Pengukuran antopometri subyek dilakukan untuk menentukan status gizi berdasarkan BMI for age percentile. Pengukuran berat badan diukur menggunakan timbangan berat badan dengan ketelitian $0,1 \mathrm{~kg}$. Tinggi badan diukur menggunakan microtoise dengan ketelitian $0,1 \mathrm{~cm}$ dan lingkar pinggang diukur menggunakan pita ukur. Pengukuran tekanan darah dilakukan oleh tenaga ahli menggunakan Sphygmomanometer air raksa. Tekanan darah diukur menggunakan metode tidak langsung dengan cara auskultasi. Tekanan darah subyek dikatakan tinggi apabila salah satu atau keduanya $\geq$ persentil ke 90 . Persentil ke 90 untuk lingkar pinggang dan tekanan darah pada remaja yaitu lingkar pinggang untuk laki-laki $93 \mathrm{~cm}$ dan perempuan $87 \mathrm{~cm}$, serta tekanan darah sistolik 122 $\mathrm{mmHg}$ dan tekanan darah diastolik $77 \mathrm{mmHg}$. Pengambilan darah puasa dilakukan oleh petugas laboratorium terakreditasi.

Penentuan sindrom metabolik ditentukan berdasarkan kriteria dari National Cholesterol Education Program Adult Treatment Panel III (NCEP ATP III) yaitu seseorang dikatakan mengalami sindrom metabolik bila memiliki sedikitnya 3 kriteria dari 5 kriteria sebagai berikut yaitu mengalami obesitas sentral (lingkar perut $\geq$ persentil ke-90), hipertensi (tekanan darah $\geq$ persentil ke-90), kadar trigliserida $\geq 110 \mathrm{mg} / \mathrm{dl}$, kadar kolesterol HDL $\leq 40 \mathrm{mg} / \mathrm{dl}$, dan kadar glukosa darah puasa $\geq 110 \mathrm{mg} / \mathrm{dl}$, sedangkan kriteria subyek termasuk pra sindrom metabolik jika memenuhi 1-2 faktor risiko sindrom metabolik. Pra sindrom metabolik merupakan bentuk sindrom metabolik dengan derajat keparahan yang ringan.

Asupan asam lemak jenuh merupakan ratarata asupan asam lemak jenuh dari makanan yang diperoleh secara langsung menggunakan Food Frequency Questionare (FFQ), yang kemudian dikonversikan ke dalam satuan gram/hari. Asupan asam lemak jenuh dikatakan tinggi apabila $>7 \%$ dari total kebutuhan energi berdasarkan Angka Kecukupan Gizi (AKG) 2013 yaitu pada laki-laki $>20,8$ gr/hari dan pada perempuan > 16,5 gr/hari. ${ }^{14}$ Asupan kolesterol merupakan rata-rata asupan kolesterol dari makanan yang diperoleh secara langsung menggunakan Food Frequency Questionare (FFQ), yang kemudian dikonversikan 
ke dalam satuan gram/hari. Asupan kolesterol dikatakan tinggi bila > $200 \mathrm{mg} / \mathrm{hari} .{ }^{14}$ Kadar HDL merupakan kadar High Density Lipoprotein dalam plasma darah. Kolesterol HDL dikatakan rendah apabila kadarnya $\leq 40 \mathrm{mg} / \mathrm{dL}$. Kadar HDL diperiksa menggunakan magnesium-dextran sulfate precipitation reagent untuk memisahkan kolesterol HDL yang diuji secara enzimatik di Laboratorium Permata Semarang. ${ }^{15}$ Kadar CRP merupakan kadar CRP dalam plasma darah yang muncul sebagai respon terhadap inflamasi. Pemeriksaan kadar CRP dilakukan di Laboratorium Permata menggunakan metode aglutinasi, kadar CRP dikatakan tinggi apabila kadarnya $>6 \mathrm{mg} / \mathrm{L} .{ }^{15}$

Pengolahan dan analisis data menggunakan program komputer. Analisis univariat digunakan untuk mengetahui karakteristik subyek penelitian. Pengujian distribusi data dilakukan dengan uji Saphiro-Wilk untuk mengetahui normalitas data. Analisis bivariat menggunakan uji Pearson atau
Spearman untuk mengetahui hubungan asupan lemak dengan faktor risiko sindrom metabolik. Besar risiko asupan asam lemak jenuh, asupan kolesterol, dan kadar HDL terhadap peningkatan kadar $C$-reactive protein dihitung menggunakan nilai rasio prevalensi (RP).

\section{HASIL PENELITIAN \\ Karakteristik Subyek}

Hasil skrining awal yang melibatkan 835 subyek yang berasal dari SMA Negeri 2 Semarang menunjukkan $80 \quad(9,58 \%)$ siswa mengalami overweight, 66 (7,9\%) siswa mengalami obesitas, $61(7,3 \%)$ siswa mengalami obesitas sentral, dan $10(1,2 \%)$ siswa mengalami sindrom metabolik. Pada siswa dengan obesitas ditemukan prevalensi pra sindrom metabolik sebesar 94,2\% dan prevalensi sindrom metabolik sebesar $15,2 \%$. Karakteristik subyek penelitian ditunjukkan pada tabel 1 .

Tabel 1. Status Gizi dan Faktor Risiko Sindrom Metabolik pada Subyek

\begin{tabular}{|c|c|c|}
\hline Variabel & Sindrom Metabolik & Pra Sindrom Metabolik \\
\hline Total & $\mathrm{n}=10$ & $\mathrm{n}=37$ \\
\hline Usia (th) & $16,5(15-17)^{* *}$ & $16(15-17)^{* *}$ \\
\hline $\operatorname{IMT}\left(\mathrm{Kg} / \mathrm{m}^{2}\right)$ & $32,5(29.6-45,6)^{* *}$ & $30,3(25,9-43,3)^{* *}$ \\
\hline Lingkar Pinggang $(\mathrm{cm})$ & $105(97,5-120,3)^{* *}$ & $93,5(87-134)^{* * *}$ \\
\hline TD Sistol (mmHg) & $130(120-140)^{* *}$ & $110(100-140)^{* *}$ \\
\hline TD Diastol (mmHg) & $70(70-80)^{* *}$ & $70(70-80)^{* *}$ \\
\hline $\mathrm{GDP}(\mathrm{mg} / \mathrm{dL})$ & $79,9 \pm 10,9^{*}$ & $82,2 \pm 6,2^{*}$ \\
\hline Trigliserida(mg/dL) & $119(72-181)^{* *}$ & $72(50-135)^{* *}$ \\
\hline Kolesterol HDL(mg/dL) & $32,5(30-48)^{* *}$ & $42(30-56)^{* *}$ \\
\hline Laki-laki & $\mathrm{n}=10$ & $\mathrm{n}=18$ \\
\hline Usia (th) & $16,5(15-17)^{* *}$ & $16(15-17)^{* *}$ \\
\hline $\operatorname{IMT}\left(\mathrm{Kg} / \mathrm{m}^{2}\right)$ & $32,6(29,6-45,6)^{* *}$ & $30,3(25,9-43,3)^{* *}$ \\
\hline Lingkar Pinggang $(\mathrm{cm})$ & $105,9 \pm 8,1^{*}$ & $101,4 \pm 10,3^{*}$ \\
\hline TD Sistol (mmHg) & $130(120-140)^{* *}$ & $120(110-140)^{* *}$ \\
\hline TD Diastol (mmHg) & $70(70-80)^{* *}$ & $70(70-80)^{* *}$ \\
\hline $\mathrm{GDP}(\mathrm{mg} / \mathrm{dL})$ & $79,9 \pm 10,9^{*}$ & $83,6 \pm 5,6^{*}$ \\
\hline Trigliserida(mg/dL) & $117,2 \pm 32,5^{*}$ & $76,5 \pm 15,2^{*}$ \\
\hline Kolesterol HDL(mg/dL) & $32,5(30-48)^{* *}$ & $40(30-56) * *$ \\
\hline Perempuan & & $\mathrm{n}=19$ \\
\hline Usia (th) & - & $16(15-17)^{* *}$ \\
\hline $\operatorname{IMT}\left(\mathrm{Kg} / \mathrm{m}^{2}\right)$ & - & $31,4 \pm 2,8^{*}$ \\
\hline Lingkar Pinggang $(\mathrm{cm})$ & - & $90(87-114,4)^{* *}$ \\
\hline TD Sistol $(\mathrm{mmHg})$ & - & $110(100-120)^{* *}$ \\
\hline TD Diastol (mmHg) & - & $70(70-70)^{* *}$ \\
\hline GDP $(\mathrm{mg} / \mathrm{dL})$ & - & $81 \pm 6,6^{*}$ \\
\hline Trigliserida(mg/dL) & - & $51(50-135)^{* *}$ \\
\hline Kolesterol HDL(mg/dL) & - & $44,1 \pm 6,1^{*}$ \\
\hline
\end{tabular}

${ }^{*}$ nilai mean ${ }^{* *}$ nilai median (minimum-maksimum)

IMT Indeks Massa Tubuh, LP Lingkar Pinggang,TDSTekanan Darah Sistol, TDD Tekanan Darah Diastol, GDP Gula Darah Puasa, $T G$ Trigliserida, $H D L$ High Density Lipoprotein. 
Pada tabel 1 menunjukkan perbedaan pada variabel usia, IMT, lingkar pinggang, tekanan darah, dan trigliserida yang menunjukkan nilai median yang lebih tinggi pada remaja sindrom metabolik, sementara nilai median untuk kadar HDL pada remaja sindrom metabolik lebih rendah dibandingkan pada remaja pra sindrom metabolik. Pada variabel GDP menunjukkan nilai rata-rata yang masih normal, akan tetapi rata-rata kadar GDP pada remaja pra sindrom metabolik lebih tinggi dibandingkan remaja sindrom metabolik.

Hasil yang sama juga ditunjukkan pada subyek laki-laki, dimana nilai median untuk usia,
IMT, dan tekanan darah lebih tinggi pada remaja sindrom metabolik dibandingkan pada remaja pra sindrom metabolik, sementara nilai median untuk kadar HDL remaja sindrom metabolik lebih rendah dibandingkan remaja pra sindrom metabolik. Nilai rata-rata lingkar pinggang dan trigliserida untuk subyek laki-laki pada remaja sindrom metabolik lebih tinggi dibandingkan dengan remaja pra sindrom metabolik, sementara kadar GDP remaja sindrom metabolik lebih rendah. Pada subyek perempuan tidak ditemukan subyek yang mengalami sindrom metabolik.

Tabel 2. Frekuensi Faktor Risiko Sindrom Metabolik

\begin{tabular}{|c|c|c|c|c|}
\hline Komponen & \multicolumn{2}{|c|}{$\begin{array}{c}\text { Sindrom } \\
\text { Metabolik }\end{array}$} & \multicolumn{2}{|c|}{$\begin{array}{c}\text { Pra Sindrom } \\
\text { Metabolik }\end{array}$} \\
\hline Total & \multicolumn{2}{|c|}{$\mathrm{n}=10$} & \multicolumn{2}{|c|}{$\mathrm{n}=37$} \\
\hline LP (obesitas sentral) & 10 & $100 \%$ & 37 & $100 \%$ \\
\hline $\mathrm{TDS} \geq 122 \mathrm{mmHg}$ & 8 & $80 \%$ & 2 & $5,4 \%$ \\
\hline $\mathrm{TDD} \geq 77 \mathrm{mmHg}$ & 4 & $40 \%$ & 1 & $2,7 \%$ \\
\hline $\mathrm{GDP} \geq 110 \mathrm{mg} / \mathrm{dL}$ & - & - & - & - \\
\hline Trigliserida $\geq 110 \mathrm{mg} / \mathrm{dL}$ & 6 & $60 \%$ & 3 & $8,1 \%$ \\
\hline HDL $<40 \mathrm{mg} / \mathrm{dL}$ & 9 & $90 \%$ & 13 & $35,1 \%$ \\
\hline Laki-laki & \multicolumn{2}{|c|}{$\mathrm{n}=10$} & \multicolumn{2}{|c|}{$\mathrm{n}=18$} \\
\hline Obesitas sentral $(\mathrm{LP}>93)$ & 10 & $100 \%$ & 18 & $100 \%$ \\
\hline $\mathrm{TDS} \geq 122 \mathrm{mmHg}$ & 8 & $80 \%$ & 2 & $11,1 \%$ \\
\hline $\mathrm{TDD} \geq 77 \mathrm{mmHg}$ & 4 & $40 \%$ & 1 & $5,6 \%$ \\
\hline $\mathrm{GDP} \geq 100 \mathrm{mg} / \mathrm{dL}$ & - & - & - & - \\
\hline Trigliserida $\geq 110 \mathrm{mg} / \mathrm{dL}$ & 6 & $60 \%$ & - & - \\
\hline $\mathrm{HDL}<40 \mathrm{mg} / \mathrm{dL}$ & 9 & $90 \%$ & 9 & $50 \%$ \\
\hline Perempuan & & & \multicolumn{2}{|c|}{$\mathrm{n}=19$} \\
\hline Obesitas sentral $(\mathrm{LP}>87)$ & - & - & 19 & $100 \%$ \\
\hline $\mathrm{TDS} \geq 122 \mathrm{mmHg}$ & - & - & - & - \\
\hline $\mathrm{TDD} \geq 77 \mathrm{mmHg}$ & - & - & - & - \\
\hline $\mathrm{GDP} \geq 110 \mathrm{mg} / \mathrm{dL}$ & - & - & - & - \\
\hline Trigliserida $\geq 110 \mathrm{mg} / \mathrm{dL}$ & - & - & 3 & $15,8 \%$ \\
\hline $\mathrm{HDL}<40 \mathrm{mg} / \mathrm{dL}$ & - & - & 4 & $21,1 \%$ \\
\hline
\end{tabular}

Catatan : IMT=Indeks Massa Tubuh, LP=Lingkar Pinggang, TDS=Tekanan Darah Sistol, TDD=Tekanan Darah Diastol, GDP=Gula Darah Puasa, TG=Trigliserida, HDL=High Density Lipoprotein.

Tabel 2 menunjukkan frekuensi faktor risiko sindrom metabolik dimana perubahan nilai lingkar perut memiliki frekuensi terbesar diikuti oleh perubahan pada kadar HDL, tekanan darah sistol, trigliserida, dan tekanan darah diastol pada remaja sindrom metabolik. Kadar GDP pada semua subyek penelitian berada pada nilai normal. Perbedaan frekuensi faktor risiko sindrom metabolik ditunjukkan oleh tekanan darah sistol, tekanan darah diastol, kadar trigliserida, dan kadar HDL yang lebih banyak terdapat pada remaja sindrom metabolik dibandingkan remaja pra sindrom metabolik. Pada subyek laki-laki perbedaan frekuensi faktor risiko sindrom metabolik ditunjukkan pada komponen tekanan darah, kadar trigliserida, dan kadar HDL.

Tabel 3. Karakteristik Subyek Penelitian Berdasarkan Kadar CRP

\begin{tabular}{lcccc}
\hline \multirow{2}{*}{ Karakteristik } & \multicolumn{2}{c}{ Kadar CRP Normal } & \multicolumn{2}{c}{ Kadar CRP Tinggi } \\
\cline { 2 - 5 } & $\mathbf{N}$ & $\mathbf{\%}$ & $\mathbf{N}$ & $\mathbf{\%}$ \\
\hline Jenis kelamin & & & & \\
Laki-laki & 18 & $72 \%$ & 6 & $46,2 \%$ \\
Perempuan & 7 & $28 \%$ & 7 & $53,8 \%$ \\
Total & 25 & $100 \%$ & 13 & $100 \%$ \\
\hline
\end{tabular}


Tabel 3 menunjukkan peningkatan kadar CRP paling banyak ditemukan pada subyek perempuan dibandingkan pada subyek laki-laki.
Hubungan Asupan Asam Lemak Jenuh dan Asupan Kolesterol dengan Faktor Risiko Sindrom Metabolik

Tabel 4. Hubungan Asupan Asam Lemak Jenuh dan Asupan Kolesterol dengan Faktor Risiko Sindrom Metabolik

\begin{tabular}{lcccc}
\hline \multirow{2}{*}{ Variabel } & \multicolumn{2}{c}{ Asupan Asam Lemak Jenuh } & \multicolumn{2}{c}{ Asupan Kolesterol } \\
\cline { 2 - 5 } & $\mathbf{r}$ & $\mathbf{p}$ & $\mathbf{r}$ & $\mathbf{p}$ \\
\hline Lingkar Pinggang (cm) & $0,406^{*}$ & 0,011 & 0,156 & 0,349 \\
TD Sistol(mm/Hg) & 0,240 & 0,146 & 0,282 & 0,086 \\
TD Diastol (mm/Hg) & 0,073 & 0,661 & 0,013 & 0,937 \\
GDP (mg/dL) & $-0,016$ & 0,926 & $-0,093$ & 0,578 \\
Trigliserida (mg/dL) & $0,392^{*}$ & 0,015 & 0,168 & 0,312 \\
HDL (mg/dL) & $-0,322^{*}$ & 0,048 & $-0,496^{* *}$ & 0,002 \\
\hline
\end{tabular}

Catatan:

p $<0,05^{* *}<0,01$

Pada tabel 4 menunjukkan asupan asam lemak jenuh berhubungan positif dengan lingkar pinggang dan kadar trigliserida, serta berhubungan negatif dengan kadar kolesterol HDL. Sementara asupan kolesterol berhubungan negatif dengan kadar HDL.

Hubungan Asupan Asam Lemak Jenuh, Asupan Kolesterol, dan Kadar HDL dengan Kadar CRP Tinggi

Tabel 5. Hubungan Asupan Asam Lemak Jenuh, Asupan Kolesterol, dan Kadar HDL dengan Kadar CRP

\begin{tabular}{lcc}
\multicolumn{1}{c}{ Variabel } & \multicolumn{2}{c}{ Kadar CRP } \\
\cline { 2 - 3 } & r & $\boldsymbol{p}$ \\
\hline Asupan asam lemak jenuh (gr) & $0,355^{*}$ & 0,029 \\
Asupan Kolesterol (gr) & $0,325^{*}$ & 0,047 \\
Kolesterol HDL (mg/dL) & 0,015 & 0,930 \\
\hline
\end{tabular}

Catatan: * $\mathrm{p}<0,05$

Pada tabel 5 menunjukkan kadar CRP Asupan Asam Lemak Jenuh, Asupan berhubungan positif dengan asupan asam lemak Kolesterol, dan Kadar High Density Lipoprotein jenuh dan asupan kolesterol, namun tidak (HDL) sebagai Faktor Risiko Peningkatan berhubungan dengan kadar kolesterol HDL. Kadar CRP

Tabel 6. Asupan Asam Lemak Jenuh, Asupan Kolesterol, dan Kadar High Density Lipoprotein (HDL) sebagai Faktor Risiko Peningkatan Kadar CRP

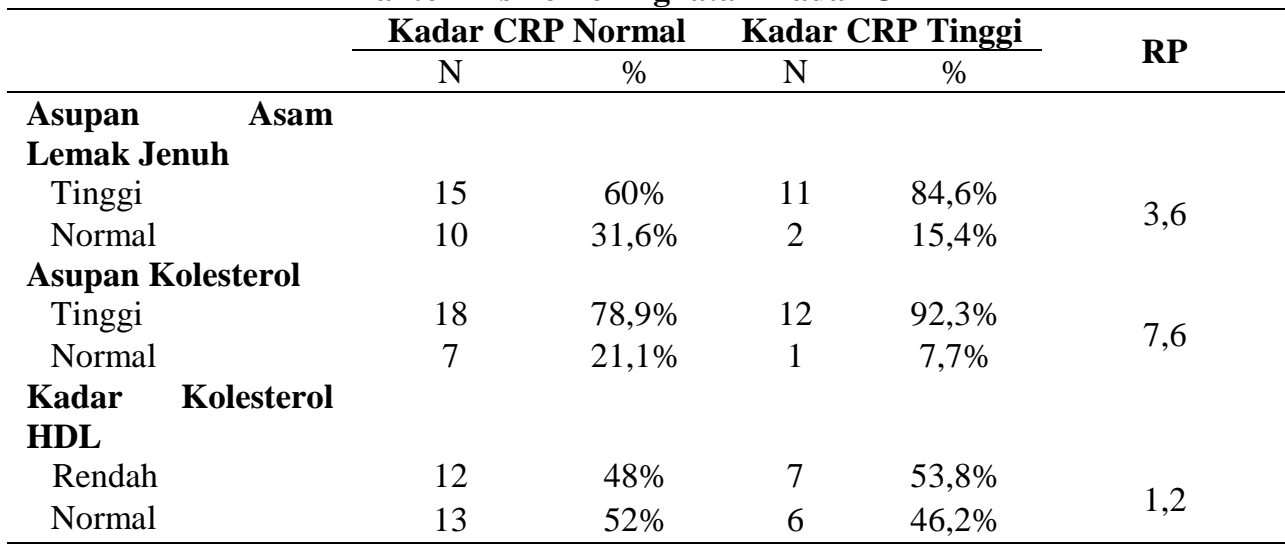

Pada tabel 6 menunjukkan $60 \%$ dan $78,9 \%$ remaja yang memiliki kadar CRP tinggi memiliki asupan asam lemak jenuh dan asupan kolesterol yang tinggi. Asupan asam lemak jenuh tinggi berisiko 3,6 kali lebih besar mengalami peningkatan kadar CRP dan remaja dengan asupan kolesterol tinggi berisiko 7,6 kali lebih besar mengalami peningkatan kadar CRP dibandingkan 
remaja dengan asupan asam lemak jenuh dan asupan kolesteol yang normal. Selain itu, sebanyak 53,8\% remaja dengan kadar CRP tinggi memiliki kadar HDL rendah dan menunjukkan remaja dengan kadar HDL rendah berisiko 1,2 kali lebih besar mengalami peningkatan kadar CRP dibanding remaja dengan kadar HDL normal.

\section{PEMBAHASAN}

Berdasarkan hasil penelitian ini ditemukan prevalensi obesitas pada remaja di SMA Negeri 2 Semarang sebesar 7,9\%, hasil ini lebih tinggi dibandingkan prevalensi obesitas di Indonesia berdasarkan hasil Riset Kesehatan Dasar (Riskesdas) tahun 2013, dimana prevalensi obesitas pada remaja berusia 16-18 tahun sebesar $1,6 \%{ }^{16}$ Meningkatnya kejadian obesitas pada remaja menunjukkan bahwa obesitas merupakan masalah yang terus berkembang dan dapat meningkatkan risiko terjadinya sindrom metabolik pada remaja. ${ }^{17}$ Pada remaja obesitas di SMA Negeri 2 Semarang juga ditemukan prevalensi sindrom metabolik sebesar $15,2 \%$, hasil ini lebih rendah dibandingkan prevalensi sindrom metabolik pada remaja obesitas di salah satu SMP swasta di Semarang pada tahun 2009 yakni 31,6\%. ${ }^{5}$ Hal karena adanya perbedaan status sosial ekonomi dan kebiasaan makan yang berbeda pada remaja di SMP tersebut dengan remaja pada penelitian ini.

Kejadian sindrom metabolik pada penelitian ini hanya ditunjukkan oleh subyek lakilaki, sementara pada subyek perempuan baru terjadi pra sindrom metabolik. Hasil ini sesuai dengan penelitian yang dilakukan oleh NHANES pada subyek remaja tahun 2001-2006, dimana prevalensi sindrom metabolik lebih besar pada laki-laki $(10,8 \%)$ dibandingkan subyek perempuan $(6,1 \%) .{ }^{1} \mathrm{Hal}$ ini dapat terjadi karena pada laki-laki deposit lemak lebih banyak disimpan dalam rongga dada dan abdomen, dimana lemak intra abdomen lebih sensitive terhadap stimulus lipolisis, memiliki kapasitas lebih besar menghasilkan asam lemak bebas, selain itu lemak yang dilepaskan dari daerah ini langsung dibawa ke hati melalui vena porta yang dapat memicu respon metabolik, sementara pada perempuan terdapat hormon estrogen yang apabila terjadi deposit lemak maka akan merangsang deposisi lemak pada jaringan subkutan. Lemak subkutan lebih resisten terhadap lipolisis dan lebih terlindungi dari fluktuasi harian, hal inilah yang menyebabkan kejadian sindrom metabolik lebih banyak terjadi pada laki-laki dibandingkan perempuan. ${ }^{17}$
Pada penelitian ini, gangguan yang banyak terjadi pada remaja sindrom metabolik adalah perubahan nilai lingkar pinggang diikuti oleh perubahan pada kadar HDL, tekanan darah, dan trigliserida, sementara kadar gula darah puasa masih dalam batas normal. Hasil penelitian ini sesuai dengan penelitian yang dilakukan pada remaja di Brasil tahun 2013 yang menunjukkan gangguan yang paling banyak terjadi pada remaja dengan sindrom metabolik adalah lingkar pinggang yang diikuti oleh penurunan kadar HDL, tekanan darah, trigliserida, dan kadar gula darah puasa. ${ }^{18}$ Pada penelitian ini lingkar pinggang merupakan kriteria dalam skrining awal penelitian sehingga semua subyek memiliki nilai lingkar pinggang diatas persentil ke-90, meskipun demikian hasil ini sesuai dengan penelitian yang dilakukan pada remaja di kota Malang tahun 2011 dimana gangguan yang paling banyak ditemui pada remaja dengan sindrom metabolik adalah pada lingkar pinggang, namun nilai rata-rata lingkar pinggang pada penelitian ini menunjukkan hasil yang lebih tinggi dibandingkan nilai rata-rata lingkar pinggang pada penelitian di kota Malang tersebut yakni rata-rata lingkar pinggang pada penelitian ini adalah $105,9 \pm 81 \mathrm{~cm}$, sementara rata-rata lingkar pinggang remaja sindrom metabolik di Kota Malang adalah $93,4 \pm 6,2 \mathrm{~cm} .{ }^{19}$ Selain itu, nilai ratarata kadar gula darah puasa pada penelitian ini masih dalam batas normal, yang menunjukkan pada remaja belum terjadi kelainan metabolisme karbohidrat karena pada kondisi normal, tubuh dapat melakukan kompensasi pada kondisi hiperglikemia dimana pankreas akan meningkatkan sekresi insulin yang menyebabkan insulin dalam plasma meningkat sehingga kadar glukosa menjadi normal kembali. ${ }^{20}$

Pada remaja obesitas, peningkatan terhadap faktor risiko sindrom metabolik sangat dipengaruhi oleh asupan makanan. Asupan makan dalam jumlah berlebih yang tidak diimbangi dengan pengeluaran energi yang seimbang dapat menyebabkan terjadinya obesitas. Obesitas memicu kondisi inflamasi kronik tingkat rendah terutama pada jaringan adiposa putih yang ditandai dengan adanya akumulasi makrofag. ${ }^{21}$ Asupan makan dalam jumlah berlebih yang berpotensi menimbulkan obesitas salah satunya adalah asupan tinggi lemak yang merupakan makanan tinggi kalori.

Berdasarkan hasil penelitian ini ditemukan adanya hubungan antara asupan asam lemak jenuh dengan lingkar pinggang, kadar trigliserida dan kadar HDL serta terdapat hubungan antara asupan 
koleterol dan kadar HDL yang rendah. Hal ini terjadi karena asupan makanan tinggi lemak dapat menyebabkan peningkatan lemak viseral pada obesitas sentral. Asupan lemak berlebih akan mempengaruhi jaringan adiposa terutama lemak viseral untuk mengekspresikan respon terhadap berbagai rangsangan salah satunya adalah peningkatan pengeluaran asam lemak bebas oleh jaringan adiposa yang dapat merangsang peningkatan sekresi VLDL di hepar yang selanjutnya akan menghasilkan peningkatan trigliserida, LDL, dan penurunan HDL. ${ }^{22}$ Selain itu,hasil penelitian ini juga menunjukkan asupan tinggi asam lemak jenuh berisiko 3,6 kali lebih besar untuk meningkatkan kadar CRP dan asupan tinggi kolesterol berisiko 7,6 kali lebih besar untuk meningkatkan kadar CRP, serta ditemukan hubungan yang signifikan antara asupan asam lemak jenuh dan asupan kolesterol dengan kadar CRP. Hasil penelitian ini sejalan dengan penelitian yang dilakukan tahun 2005 yang menunjukkan peningkatan konsumsi asam lemak jenuh berhubungan dengan status proinflamasi. ${ }^{7}$

Mekanisme yang dapat mendasari hal tersebut adalah makanan yang tinggi lemak akan menyebabkan kadar LDL dan kolesterol di sirkulasi meningkat. Peningkatan itu akan memicu pengeluaran HDL dari hati untuk mengangkut kolesterol di sirkulasi (reverse cholesterol transport). HDL ini diesterifikasi menjadi ester kolesterol yang dapat langsung dibawa ke hati untuk langsung diekskresi atau ditukar dengan trigliserida dari VLDL dan kilomikron. Ketika ester kolesterol berlebih, HDL yang kaya akan trigliserida (HDL densitas rendah) dipecah oleh lipase hepatik sehingga menurunkan kadar HDL yang bersirkulasi. Akibatnya proses reverse cholesterol transport berkurang dan kadar kolesterol dalam sirkulasi dan jaringan meningkat. Pada suatu kondisi, peningkatan kadar kolesterol berlebih di sirkulasi menyebabkan suatu reaksi abnormal yang menyebabkan aktivasi makrofag scavenger. Makrofag ini bertugas untuk membersihkan kolesterol dan HDL densitas rendah dari sirkulasi dengan cara fagositosis. Makrofag yang penuh dengan kolesterol selanjutnya akan menjadi sel busa yang menyebabkan aktivasi sitokin pro inflamasi (IL-1, IL-6, dan TNF $\alpha$ ). Aktivasi sitokin pro inflamasi ini merupakan tanda awal terjadinya peradangan. Peradangan yang berlanjut akan menyebabkan pengeluaran CRP dari hati. ${ }^{17,23}$ Mekanisme ini juga mendukung hasil penelitian yang menunjukkan remaja dengan kadar HDL yang rendah berisiko 1,2 kali lebih besar meningkatkan kadar CRP dibandingkan remaja dengan kadar HDL normal. Meskipun demikian pada penelitian ini tidak ditemukan adanya hubungan antara kadar HDL dengan kadar CRP, hasil ini tidak sesuai dengan penelitian yang dilakukan pada remaja di Brasil tahun 2013 yakni terdapat hubungan antara kadar CRP dengan kadar kolesterol HDL $(p=0,003){ }^{24}$ Hal ini dapat disebabkan karena jumlah sampel yang diteliti dalam pengujian hubungan kadar HDL dengan kadar CRP dalam jumlah yang sedikit, sehingga mempengaruhi hasil uji statistik yang menunjukkan tidak ada hubungan.

Peningkatan kadar CRP pada penelitian ini lebih banyak terjadi pada perempuan dibandingkan laki-laki, hasil ini sesuai dengan penelitian yang dilakukan pada remaja usia 11-15 tahun di Brasil tahun 2013 dimana peningkatan kadar CRP lebih banyak ditemukan pada perempuan dibandingkan laki-laki. Hal ini disebabkan karena persen lemak tubuh yang lebih tinggi dan jaringan adiposa yang lebih tebal pada perempuan dibanding laki-laki. ${ }^{24}$ Kelebihan jaringan adiposa dapat mensekresikan adipokin inflamasi seperti interleukin (IL)-6 dan Tumor Necrosis Factor $\alpha$ (TNF $\alpha)$ yang selanjutnya dapat merangsang hepar untuk memproduksi CRP. ${ }^{25}$

\section{SIMPULAN}

Prevalensi sindrom metabolik pada remaja obesitas di SMA Negeri 2 Semarang adalah 15,2\%. Sebanyak 84,6\%; 92,3\%; dan $53,8 \%$ remaja obesitas dengan kadar CRP tinggi secara berurutan memiliki asupan asam lemak jenuh tinggi, asupan kolesterol tinggi, dan kadar HDL yang rendah. Asupan tinggi asam lemak jenuh, asupan tinggi kolesterol, dan kadar HDL yang rendah merupakan faktor risiko terhadap peningkatan kadar CRP pada remaja obesitas dengan sindrom metabolik, dengan besar risiko secara berurutan 3,7 kali; 4,7 kali; dan 1,3 kali.

\section{SARAN}

Perlu dilakukan intervensi kepada remaja yang telah mengalami sindrom metabolik pada penelitian ini sebagai pencegahan terjadinya sindrom metabolik pada saat dewasa, salah satunya adalah dengan pengaturan asupan makan yaitu dengan membatasi asupan tinggi asam lemak jenuh dan asupan tinggi kolesterol.

\section{DAFTAR PUSTAKA}

1. Johnson WD, Kroon JJ, Greenway FL, Bouchard C, Ryan D, Katzmarzyk PT. Prevalence of Risk 
Factors for Metabolic Syndrome in Adolescents National Health and Nutrition Examination Survey (NHNES), 2001-2006. Arch Pediatr Adolesc Med. 2009;163(4):371-377.

2. Duncan GE, Li SM, Zhou XH. Prevalence and Trends of a Metabolic Syndrome Phenotype Among U.S. Adolescents 1999-2000. Diabetes Care 2004; 27: 2438-2443

3. Dwipayana MP, et al. Prevalensi Sindroma Metabolik Pada Populasi Penduduk Bali, Indonesia. Jurnal Penaykit Dalam, Vol. 12 No. 1. 2011

4. Mexitalia M, dkk. Sindroma Matabolik Pada Remaja. Media Medika Indonesiana.2009; Vol 43. No 6.

5. Abudayya A.H.,et al. Sociodemoghrapic Correlation of Food Habits Among School Adolescent (12-15 year) in North Gaza Strip, Norway: University of Oslo. 2009.

6. Poledne R. A New Atherogenic Effect of Saturated Fatty Acids.Physiol.Res. 62: 139-143, 2013.

7. Uganami T, Nishida J, Ogawa Y. A Paracrine Loop Between Adipocytes and Macrophages Aggravates Inflammatory Changes: Role of Free FattyAacids and Tumor Necrosis Factor Alpha. Arterioscler Thromb Vasc Biol 25: 2062-2068, 2005.

8. Expert Panel on DetecCon. Evaluation, and Treatment of High Blood Cholesterol in Adults. Executive Summary of the Third Report of the National Cholesterol Education Program (NCEP) Expert Panel on Detection, Evaluation, and Treatment of High Blood Cholesterol in Adults (Adult Treatment Panel Ill). JAMA 2001,285:248697.

9. Colpo A. LDL cholesterol "Bad" cholesterol, or Bad Science. Journal of American Physician an Surgeons, 2005:10:3:83-89.

10. Oliviera AC, Oliveira AM, Adan LF, Oliveira NF, et al. C-reactif Protein and Metabolic Syndrome in Youth: A Strong Relationship. Articles Epidemiology Vol.16 No.5. 2008

11. Guillen LS, Garcia BH, Pita J, Garrido ND, Camacho GD, Rovira A. High-Sensitivity CReactive Protein is a Good Marker of Cardiovascular Risk in Obes Children And Adolescents. European Journal of Endocrinology. 2008. 159 R1-R4. ISSN 0804-4643.

12. Nyandak T, Gogna A, Bansal S, Deb M. High Sensitive C-Reactive Protein (hsCRP) and its Correlation with Angiographic Severity of Coronary Artery Disease (CAD). JIACM 2007;8(3):217-21.

13. Ferranti SD, Gauvreau K, Ludwig DS, Newburger JW, Rifai N. Abnormalities in US Ford ES, Giles WH. Dietz WH. Prevalence of the Metabolic Syndrome among US Adults: Findings from thc TbYr: National and Nutrition Examination Survey. JAMA 2002,287:356-9.
14. Lichtenstein AH, Appel LJ, Brands M, et al. Diet and Lifestyle Recommendation revission 2006: A scientific statement from the American Heart Assotiation Nutrition Committee Circulation AHA. 2006, (114) 82-96.

15. Gallager ML. The Nutrient and Their Metabolism. In LK, Sylvia ES, editors. Krause's Food, Nutrient and Diet Therapy. $12^{\text {th }}$ edition. USA. Saunders. 2008. 3. 50-59.

16. Badan Litbang Kesehatan Departemen Kesehatan RI. Laporan Hasil Riset Kesehatan Dasar (RISKESDAS) Nasional 2013. Jakarta.

17. Barasi, ME. At Glance Ilmu Gizi. Jakarta: Penerbit Erlangga;2009.

18. Rizzo AC, Goldberg TB, Silva CC, Kurokawa CS, Nunes HR, Corrente JE. Metabolic Syndrome Risk Factors in Overweight, Obes, and Extremely Obese Brazillian Adolescent. Nutrition Journal. 2013;1475-2891.

19. Sargowo D, Andarini S. The Relationship Between Food Intake and Adolescent Metabolic Syndrome. J Kardiol Indones. 2011;32:14-23.

20. Buse JB, Kenneth SP \& Charles FB. Type 2 Diabetes Mellitus. William Textbook of Endocrinology 2002:1427-1451.

21. Wellen K, Hostamisligil GS. InflammationInduced Inflammatory Changes in Adiposa Tissue. J Clin Invest, 2003;112:1785-1788

22. Wang Hao, Peng DQ. New Insight into the Mechanism of Low High Density Lipoprotein Cholesterol in Obesity. Lipids in Health and Disease 2011, 10:176

23. Murray RK, Granner DK, Rodwell VW. Biokimia Harper. Jakarta: EGC;2009.

24. Cruz LL, Cardoso LD, Pala D, Paula H, Lamounier JA, Silva CAM, et al. Metabolic Syndrome Components Can Predict C-Reactive Protein Concentration in Adolescents. Nutr Hosp. 2013;28:1580-1586.

25. Lau D, Yan H, Abdel-hafez M, Kermouni A. Adipokines and the Paracrine Control of Their Production in Obesity and Diabetes. Int J Obes Relat Metab Disord 2002; 26: S111 